\title{
Aspectos patológicos, imunológicos e propriedades moleculares do $\Pi \pi$ vírus
}

\section{Pathological and immunological aspects and molecular properties of $I T$ virus}

\author{
Maria Angelica Ehara Watanabe'; Helen Cristina Miranda²; Karen Brajão de Oliveira²; Carlos Eduardo Coral de Oliveira²; \\ Fabrine Sales Massafera Tristão; Leila Maria Duarte²; Ligiane de Lourdes Silva²; Andréia Corrêa Corte²; \\ Flávia Alessandra Guarnier²; Mari Sumigawa Kaminami²
}

\begin{tabular}{l|l}
\multicolumn{1}{c|}{ unitermos } & resumo \\
\hline$\Pi$ vírus (TV) & $\begin{array}{l}\text { O TT vírus (TTV) foi primeiramente descrito no Japão, em 1997, por T. Nishizawa, no soro de pacientes } \\
\text { com hepatite, pós-transfusão, não-A-G. Tem sido intensivamente investigado, desde então, como uma } \\
\text { Doenças hepáticas }\end{array}$ \\
Hepatites virais & $\begin{array}{l}\text { possível adição à lista dos vírus indutores de hepatite. O TTV é um vírus DNA não-envelopado, de fita } \\
\text { Genoma viral } \\
\text { levado pesquisadores a agrupar isolados do vírus em inúmeros genótipos e subtipos. No entanto a } \\
\text { significância clínica da infecção por TTV permanece desconhecida. Ele é freqüentemente detectado } \\
\text { em fluidos corporais e seu componente mais bem elucidado atualmente é o genoma. Conhecimentos } \\
\text { relacionados ao TTV têm aumentado constantemente, porém vários aspectos fundamentais permanecem } \\
\text { obscuros. Esta revisão apresenta algumas das propriedades moleculares do TT vírus. }\end{array}$
\end{tabular}

abstract

TT virus (TTV) was first reported in Japan in 1997 by T. Nishizawa in sera from non-A to non-G post-transfusion hepatitis patients. It has been intensively investigated, ever since, as a possible addition to the list of hepatitisinducing viruses. The TTV is an unenveloped, single-stranded DNA virus. Considerable genetic variability of TTV has been demonstrated and has led investigators to group its isolates into numerous genotypes and subtypes. However, the clinical significance of TTV infection remains unknown. It is frequently detected in the serum and in other body fluids of humans. The component of TTV currently best understood is its genome. Knowledge related to TTV has increased rapidly, but many fundamental aspects remain unclear. This review shows some of the molecular properties of TT virus. key words

$\pi$ virus (TTV)

Liver diseases

Viral hepatitis

Viral genoma

\section{Introducão}

Nas últimas décadas, áreas relacionadas à virologia acompanharam um grande avanço na caracterização dos vírus hepatotrópicos humanos. A hepatite viral ainda é uma das causas mais comuns de doenças hepáticas aguda e crônica e atualmente pode ser dividida em dois grandes grupos: hepatites virais de $\mathrm{A}$ a $\mathrm{E}$, cujas etiologias já estão bem conhecidas e descritas; e hepatites virais non-A to non-E. $O$ segundo grupo inclui vírus recentemente descobertos, como os vírus das hepatites $\mathrm{G}$ e $\mathrm{F}$, o SEN-V e o vírus TT (TTV) (6).

O TTV foi inicialmente identificado por Nishizawa et al.(22), em 1997, em pacientes com elevados níveis de alanina aminotransferase (ALT), porém negativos para

1. Professora-adjunta do Departamento de Ciências Patológicas da Universidade Estadual de Londrina (UEL).

2. Mestrandos do Programa de Pós-Craduação em Patologia Experimental do Centro de Ciências Biológicas da UEL 
hepatites de A a G. Esse vírus tem seu nome associado às iniciais do primeiro paciente investigado pelo grupo de Nishizawa (paciente TT), contudo essas iniciais também podem designar transfusion-transmitted virus $^{(22,3)}$.

As informações limitadas sobre as propriedades físicoquímicas do TTV derivam do estudo de plasma sangüíneo e, menos comumente, de extratos fecais de indivíduos infectados. A partícula viral do TTV possui um diâmetro entre 30 e $50 \mathrm{~nm}^{(21)}$, com densidade entre 1,31 e 1,35g/ml em cloreto de césio, $1,26 \mathrm{~g} / \mathrm{ml}$ em gradientes de sacarose ${ }^{(21}$, ${ }^{24)}$, e não possui envelope lipídico externo ${ }^{(24)}$.

Os tratamentos virucidas conhecidos por inativarem os vírus envelopados (como exemplo, solvente-detergente e aquecimento a $65^{\circ} \mathrm{C} / 96$ horas a seco) parecem ser pouco efetivos na destruição da infectividade por TTV. Em contrapartida, a purificação de imunoafinidade e tratamentos mais drásticos de aquecimento de fatores de coagulação demonstram ser mais efetivos ${ }^{(5,31)}$ contra o TTV. Esses dados, juntamente com a estrutura viral conhecida, sugerem que o vírus TTV possa ser tão estável quanto os parvovírus( ${ }^{(4)}$.

As dificuldades para o estudo aprofundado desse novo vírus são inúmeras. Já existem relatos da transfecção do TTV em chimpanzés e macacos Rhesus(21, 25). Porém não há evidências sobre transfecção em mamíferos menores, devido à grande dificuldade de se obter a replicação desse vírus em cultura de tecido ${ }^{(18)}$.

Apesar de pouco conhecimento sobre as propriedades biológicas desse vírus, com o advento do seqüenciamento muito já pode ser elucidado com relação às suas propriedades moleculares. Trata-se de um vírus não-envelopado, DNA fita simples e polaridade negativa ${ }^{(39)}$.

Esta revisão tem por objetivo abordar os aspectos moleculares do TTV.

\section{Aspectos patológicos do TTV}

O papel patogênico do TTV ainda permanece sob discussão, uma vez que, inicialmente, pensava-se ser patogênico para o fígado, o que sugeriria uma falência hepática fulminante. Tawara et al. ${ }^{(35)}$, em 2000, encontraram, em seu estudo com chimpanzés, um aumento abrupto de enzimas hepáticas; por outro lado, Kato et al.(14), em seus estudos clínicos, concluíram que níveis séricos de TTV não afetam a lesão hepática devido ao vírus da hepatite.

O TTV pode causar uma infecção transitória ou persistente, sendo que no Japão foi encontrado em $47 \%$ de casos de hepatites fulminantes e crônicas não-A-G, 38\% de casos de cirrose de etiologia não-conhecida e $12 \%$ de doadores de sangue ${ }^{(24,15,31)}$. Sua presença também foi relatada em indivíduos sãos na Europa e nos Estados Unidos. No Brasil, nos estados de São Paulo e Pará, o TTV foi encontrado em pacientes com hepatopatias crônicas ${ }^{(32)}$. Os tipos 1 e 2 do TTV são os mais comuns em todas as regiões estudadas do mundo(26).

Não há manifestações clínicas exclusivamente associadas ao TTV. Pelo fato de a infecção ativa ser altamente prevalente entre indivíduos aparentemente saudáveis, há freqüentes demonstrações sugestivas de que o TTV é essencialmente desprovido de potencial patogênico. Estudos estão sendo realizados com o genótipo 1, pela possibilidade de induzir doença no ser humano, além de sua prevalência e distribuição mundial(3).

\section{Propriedades moleculares}

Okamoto et al. ${ }^{(26)}$ mostraram que o genoma viral do TTV é um DNA de fita simples, pois $97 \%$ dos ácidos nucléicos extraídos de TTV eram sensíveis à DNAse I, porém resistentes à RNAse A. Inicialmente, foi proposto um genoma viral linear, mas após a análise realizada por seqüenciamento foram evidenciadas duas extremidades conectadas por uma região rica em $\mathrm{G}+\mathrm{C}$ de aproximadamente 100 nucleotídeos, formando uma molécula circular covalentemente fechada ${ }^{(24)}$.

A princípio o TTV apresentava semelhanças com os parvovírus ${ }^{(26,19)}$, mas estruturas biofísicas e moleculares observadas por Hijikata et al.(13), em 1999, levaram Bendinelli et al.(3), em 2001, a enfatizar sua semelhança com os circovírus que, conforme Todd et al. ${ }^{(36,7)}$, possuem genomas circulares não-segmentados com capsídeos isométricos, possuindo uma simples proteína estrutural viral, com ausência de lipídios e carboidratos.

O genoma do TTV é dividido em uma região codificadora de 2,6Kb e uma região não-codificadora (UTR) de 1,2Kb, possuindo entre 3.808 nucleotídeos (isolado SANBAN) e 3.853 nucleotídeos (isolados TA278 e JA20) ${ }^{(13)}$.

A região codificadora possui dois principais genes codificadores de proteínas open reading frame (ORF1 e ORF2), de 770 e 150 aminoácidos respectivamente ${ }^{(13)}$, e em alguns isolados há também uma pequena ORF adicional (ORF3) com capacidade para codificar 57 aminoácidos ${ }^{(8)}$ (Figura). O produto da região ORF1 tem elevada proporção (aproximadamente $40 \%$ ) de resíduos de arginina nos primeiros cem aminoácidos aminoterminais ${ }^{(24)}$, possui diferentes tipos 


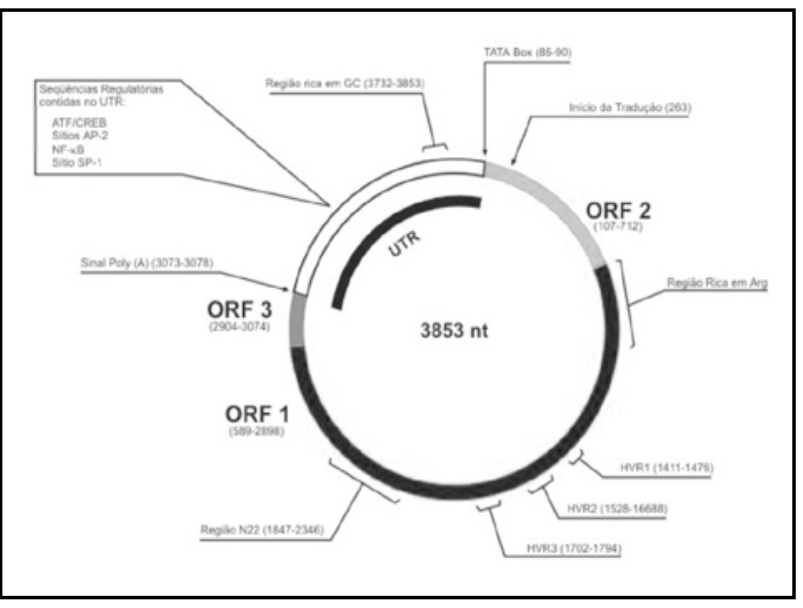

Figura - Organização genômica do TTV mostrando o DNA circular, fita simples, de polaridade negativa, encapsulado dentro do vírion. Posições nucleotídicas do isolado TA278. 0 esquema mostra as ORFs 1, 2 e 3, a região UTR, bem como outras regiões importantes. É o caso da região N22, muito utilizada para estudos epidemiológicos e genotipagem ${ }^{(3)}$

de glicosilação semelhante à asparagina nos diferentes isolados, afetando as propriedades biológicas da proteína resultante, como, por exemplo, a especificidade antigênica(13). Além dessas características, os produtos de ORF1 do TTV contêm seqüências curtas de aminoácidos características das proteínas associadas a replicação(10).

A região ORF2 codifica uma proteína não-estrutural envolvida na replicação e, apesar de ser altamente heterogênea entre os isolados de TTV, seus segmentos 46-66 contêm cinco regiões conservadas entre todos os isolados analisados por Hijikata et al. ${ }^{(13)}$ em 1999.

O TTV possui aproximadamente 18 genótipos já descritos, que divergem mais de $30 \%$ entre si na sua seqüência de nucleotídeos, e sua transmissão tem sido amplamente estudada e descrita na literatura mundial. Seu foco principal é a transmissão parenteral, através de transfusão sangüínea ${ }^{(16,29)}$ ou por hemoderivados ${ }^{(2,1)}$. Entretanto alguns estudos têm demonstrado casos de transmissão por via fecal-oral ${ }^{(32)}$, contato sexual ou transmissão mãe/filho durante a gestação ${ }^{(9,40,17)}$.

O TTV é altamente heterogêneo, em contraste com a maioria dos vírus DNA. A divergência se encontra bem elevada na região central da ORF1, onde existem regiões hipervariáveis que podem levar a mais de $70 \%$ de diversidade no aminoácido, porém a região UTR desse vírus é bem conservada ${ }^{(8,23)}$.

Têm sido verificadas a prevalência e a diversidade genética do TTV genótipo 21 no Brasil(38).

Heller et al. ${ }^{(12)}$ e Okamoto et al. ${ }^{(25)}$ têm relatado a existência de mais de 20 genótipos com divergência de mais de $30 \%$ um do outro, sendo que tais genótipos são classificados em quatro grupos filogenéticos principais, como demonstrado na Tabela.

O diagnóstico laboratorial para a infecção pelo TTV é realizado freqüentemente pela amplificação de segmentos do DNA viral, pela reação em cadeia da polimerase (PCR), utilizando-se primers designados para a região N22 da ORF1, ou para a região untranslated region (UTR) do genoma do vírus. No entanto, devido à grande variabilidade genética do TTV, alguns segmentos do DNA viral podem reduzir a sensibilidade da PCR, apesar de sua região UTR ser altamente conservada entre pelo menos 16 genótipos do vírus. Outro fator que diminui a confiabilidade dos protocolos de PCR está associado à baixa carga viral no soro humano, que não excede $10^{4}$ cópias/ml(28).

\section{Aspectos imunológicos}

Pouco se sabe sobre a vigilância imune do hospedeiro e de anticorpos anti-TTV na circulação sangüínea. Ott et al. ${ }^{(28)}$ confirmaram a existência de uma resposta imune contra o TTV em amostras de sangue de doadores e de pacientes com hepatites de etiologia desconhecida, e também em crianças e animais. Foi observada uma resposta humoral contra a região C-terminal da proteína recombinante ORF1 com 98,6\% de reatividade sorológica, indicando a alta prevalência de infecção em pacientes com hepatite de etiologia desconhecida ${ }^{(28)}$.

Poucos estudos vêm sendo realizados para detecção de anticorpos anti-TTV, talvez devido à limitada compreensão das respostas imunes induzidas pelo vírus e à dificuldade na obtenção de antígenos. Em um estudo realizado por Ott et al. ${ }^{(28)}$ na França, em 2000, uma proteína recombinante foi gerada a partir de uma seqüência da ORF1 utilizada como antígeno para a detecção de anticorpos anti-TTV por Western blot em amostras de soro de pacientes com hepatite de etiologia desconhecida. Uma alta prevalência de anticorpos TTV-específicos foi encontrada (98\%), enquanto a detecção do DNA-TTV por PCR foi de 76,1\%, nas mesmas amostras, indicando que a utilização da proteína recombinante da região ORF1 poderia representar uma ferramenta útil no diagnóstico da infecção pelo TTV e tornaria possível a avaliação da resposta imune desenvolvida contra o vírus ${ }^{(28)}$.

Estudos complementares devem ser realizados para comprovar uma possível reação cruzada com proteínas de outros organismos, principalmente entre vírus de mesma espécie. 


\begin{tabular}{|c|c|c|}
\hline Grupo & Genótipo & $\begin{array}{c}\text { Referências } \\
\text { (Número de acesso no GenBank) }\end{array}$ \\
\hline \multirow[t]{9}{*}{1} & 1 & TA278 (AB008394) Okamoto et al., 1999a \\
\hline & 2 & TS003 (AB017770) 0kamoto et al., 1999a \\
\hline & & NA004 (AB017771) ou JA1 (AF122916) \\
\hline & & TKB555 (AB017773), РT3 (AB017768), TKB212 (AB017772) \\
\hline & 3 & TKB6 (AB017774) Okamoto et al., 1999a \\
\hline & & Т3РВ (AF247138) \\
\hline & 4 & TKM1 (AB017775) Okamoto et al., 1999a \\
\hline & 5 & THEM1 (AB017776) 0kamoto et al., 1999a \\
\hline & 6 & TFC3155 (AB017777) 0kamoto et al., 1999a \\
\hline \multirow[t]{5}{*}{2} & 7 & THEM2 (AB017778) Okamoto et al., 1999a \\
\hline & 8 & THEM3 (AB017779) Okamoto et al., 1999a \\
\hline & 17 & PMV (AF261761) Hallett et al., 2000 \\
\hline & 22 & Kt-08F (AB054647) Muljono et al., 2001 \\
\hline & 23 & Kt-10F (AB054648) Muljono et al., 2001 \\
\hline \multirow[t]{13}{*}{3} & 9 & K70-56 (AB017781) 0kamoto et al., 1999a \\
\hline & & $\mathrm{K} 60-26(\mathrm{AB} 017782)$ \\
\hline & 10 & K66-46 (AB017783) 0kamoto et al., 1999a \\
\hline & 11 & TUS01 (AB017613) Okamoto et al., 1999a \\
\hline & 12 & TS3 (AB021081) Okamoto et al., 1999a \\
\hline & & TJN01 \\
\hline & 13 & TS15 (AB021089) Okamoto et al., 1999a \\
\hline & & SANBAN (AB025946) \\
\hline & 14 & TS4-I (AB021082) Okamoto et al., 1999a \\
\hline & 15 & TS5-II (AB021085) 0kamoto et al., 1999a \\
\hline & & TS13-II \\
\hline & 16 & TS5-I (AB021084) Okamoto et al., 1999a \\
\hline & 18 & TYM9 (AB05448) 0kamoto et al., 2000 \\
\hline \multirow[t]{2}{*}{4} & 21 & YONBAN (AB038621) Takahashi et al., 2000b \\
\hline & & YONBAN-Brasil (AF515680) Vasconcelos et al., 2003 \\
\hline
\end{tabular}

\section{Conclusão}

A maioria dos estudos mostrou uma alta taxa de detecção do TTV entre indivíduos politransfundidos, talassêmicos, hemodialisados, hemofílicos e usuários de drogas intravenosas. A identificação do DNA viral tem sido realizada através do ensaio de PCR nested e, além de amostras de plasma e soro, têm sido analisadas, também, amostras de fezes, saliva, swab nasal e swab da garganta.

Esse agente etiológico é um vírus não-envelopado, classificado na família Circoviridae, com um diâmetro de 30 a $50 \mathrm{~nm}$. Seu material genético é DNA de fita simples, circular de polaridade negativa e possui 3.852 nucleotídeos ${ }^{(28,33)}$. 
O componente do TTV mais explorado tem sido o genoma, cuja caracterização inicial evidenciou DNA de fita simples. O genoma do TTV foi dividido em regiões ORF1 e ORF2 e um pequeno ORF adicional, designado ORF3; além disso, já foram identificados pelo menos 16 tipos genômicos de TTV.

Pouco se sabe sobre a vigilância imune do hospedeiro e de anticorpos anti-TTV na circulação sangüínea. Foi observada resposta humoral contra a região c-terminal da proteína recombinante ORF1.

A transmissão pode ocorrer parenteralmente, através de transfusão sangüínea ou pela rota fecal-oral, e tem-se considerado a transmissão de mãe para feto. A transmissão via sexual não foi considerada importante.

Não há manifestações clínicas exclusivamente associadas ao TTV. Pelo fato de a infecção ativa ser altamente prevalente entre indivíduos aparentemente saudáveis, há freqüentes sugestões de que o TTV seja considerado essencialmente desprovido de potencial patogênico.

Evidências sugerem que o TTV não é uma causa significativa para doenças hepáticas, embora seja capaz de induzir a hepatite em uma pequena parcela de pacientes. A pesquisa do TTV em pacientes sem relatos de sintomas hepáticos auxiliará a determinar se o vírus contribui para o desenvolvimento de outras doenças.

\section{Referências}

I. ALI, S. et al.TT virus infection in acute and chronic liver diseases and in patients regularly receiving blood products in Belgium. Acta Gastroenterol Belg, v. 67, n. 2, p. 61-55, 2004.

2. BARRIL, G. et al. Guidelines on hemodialysis-associated viral infections. Nefrologia, v. 24, n. 2, p. 43-66. 2004.

3. BENDINELLI, M. et al. Molecular properties, biology, and clinical implications of TT virus a recently identified widespread infectious agent of humans. Clin Microbiol Rev, v. 14, n. I, p. 98- I 13,2001.

4. BERNS, K. I. Parvoviridae: the virus and their replication. In: FIELDS, B. N. et al. Fields virology. 3 ed. Philadelphia: Lippincot-Raven, 1996. p. 2173-99.

5. CHEN, B. P. et al.TT virus is present in a high frequency of Italian hemophilic patients transfused with plasma-derived clotting factor concentrates. Blood, v. 94, p. 4333-6, 1999.

6. DEODHARE, S. G. Patho articles. Viral hepatitis: recent progress. TTVirus (TTV). Disponível em: http://www.pathoindia.com/ update2.html (2000). Acesso em: 19 mar. 2004.

7.DINIZ-MENDES,L:;DEVALLE,S:;NIEL, C. Genomic characterization of a Brazilian TT virus isolate closely related to SEN virus-F. Mem Inst Oswaldo Cruz, v. 99, n. 3, p. 301-6, 2004.

8. ERKER, J. C. et al. Analyses of TT virus full-length genomic sequences. J Gen Virol, v. 80, p. 1743-50, 1999.

9. GOTO, K. et al. Detection rates of TT virus DNA in serum of umbilical cord blood, breast milk and saliva. Tohoku J Exp Med, v. 191, n. 4, p. 203-7, 2000.

10. HAFNER, G. J. et al. Nicking and joining activity of banana bunchy top virus replication protein in vitro. J Gen Virol, v. 78, p. 1795-9, 1997.

I I. HALLETT, R. L. et al. Characterization of a highly divergent TT virus genome.J Gen Virol, v. 8I, p. 2273-79, 2000.

12. HELLER, F. et al. Isolate KAV: a new genotype of the TT-virus family. Biochem Biophys Res Commun, v. 289, n. 5, p. 937-4I, 2001.

13. HIIIKATA, M.; TAKAHASHI, K.; MISHIRO, S. Complete circular DNA genome of a TT virus variant (isolate name SANBAN) and 44 partial ORF2 sequences implicating a great degree of diversity beyond genotypes. Virology, v. 260, p. 17-22, 1999.

14. KATO, T. et al. Development of a $T$ virus DNA quantification system using real-time detection PCR. J Clin Microbiol, v. 38, p. 94-8, 2000.

15. KATO, T. et al. High prevalence of TT virus infection among the Japanese hepatocellular carcinoma patients and blood donors. Hepatology, v. 28A, p. 519, 1998.

16. KAWANAKA, M. et al. Effect of TT virus co-infection on interferon response in chronic hepatitis $C$ patients. Liver, v. 22, n. 4, p. 35I-5, 2002.

17. KOMATSU, H. et al.TTV infection in children born to mothers infected with TTV but not with HBV, HCV, or HIV.J Med Virol, v. 74, n. 3, p. 499-506, 2004.

18. MAGGI, F. et al.TT virus (TTV) loads associated with different peripheral blood cell types and evidence for TTV replication in activated mononuclear cells. J Med Virol, v. 64, n. 2, p. 190-4, 200 I.

19. MIYATA, H. et al. Identification of a novel GC-rich I I 3-nucleotide region to complete the circular, single-stranded DNA genome of TT virus, the first human circovirus. J Virol, v. 73, p. 3582-6, 1999.

20. MULJONO, D. H. et al. Molecular epidemiology of TT virus (TTV) and characterization of two novel TTV genotypes in Indonesia. J Arch Virol, v. I46, n. 7, p. 1249-66, 200 I.

21. MUSHAHWAR, I. K. et al. Molecular and biophysical characterization of TT virus: evidence for a new virus family infecting humans. Proc Natl Acad Sci USA, v. 96, p. 3177-82, 1999.

22. NISHIZAWA, T. et al.A novel DNA virus (TTV) associated with elevated transaminase levels in post-transfusion hepatitis of unknown etiology. Biochem Biophys Res Commun, v. 24I, p. 92-7, 1997.

23. NISHIZAWA, T. et al. Quasispecies of TT virus (TTV) with sequence divergence in hypervariable regions of the capsid protein in chronic TTV infection. J Virol, v. 73, p. 9604-8, 1999. 
24. OKAMOTO, H. et al. Fecal excretion of a nonenveloped DNA virus (TTV) associated with post-transfusion non A-G hepatitis. J Med Virol, v. 56, p. 128-32, 1998a.

25. OKAMOTO, $\mathrm{H}$. et al. Marked genomic heterogeneity and frequent mixed infection of TT virus demonstrated by PCR with primers from coding and noncoding regions. J Virol, v. 259, n. 2, p. 428-36, 1999.

26. OKAMOTO, H. et al. Molecular cloning and characterization of a novel DNA virus (TTV) associated with post-transfusion hepatitis of unknown etiology. Hepatol Res, v. 10, p. 1-16, 1998b.

27. OKAMOTO, H. et al. Species-specific TT viruses and crossspecies infection in nonhuman primates. J Virol, v. 74, p. 1132-9, 2000

28. OTT, C. et al. Use of TT virus ORFI recombinant protein to detect anti-TT virus antibodies in human sera.J Gen Virol, v. 8I, p. 2949-58, 2000.

29. OZA, V. M. et al.Transfusion-transmitted virus is not present in factor IX concentrates commonly used to treat haemophilia B. Haemophilia, v. 10, n. 6, p. 732-4, 2004.

30. RIGAS, B. et al. Effect on treatment outcome of coinfection with SEN viruses in patients with hepatitis C. Lancet, v. 358, p. $1961-2,2001$.

31. SIMMONDS, P. et al. Detection of a novel DNA virus (TTV) in blood donors and blood products. Lancet, v. 352, p. 191-5, 1998.

32.TAKAHASHI, K. et al. Full or near-full length nucleotide sequences
ofT virus variants (types SANBAN and YONBAN) and the TTV-like mini virus. Intervirology, v. 43, p. I 19-23, $2000 \mathrm{~b}$.

33. TAKAHASHI, K. et al. Identification of a new human DNA virus (TTV-like minivirus, TLMV) intermediately related to TT virus and chicken anemia virus. Arch Virol, v. I 45, p. 979-93, 2000a.

34. TANAKA, T. et al. Detection and typing of TT virus DNA genotype by the PCR-RFLP method. Mol Cell Probes, v. I5, n. 4, p. 195-200, 200I.

35.TAWARA, A. et al.Transmission of human $T T$ virus of genotype Ia to chimpanzees with fecal supernatant or serum from patients with acute TTV infection. Biochem Biophys Res Commun, v. 278, n. 2, p. 470-6, 2000.

36.TODD, D. et al. Purification and biochemical characterization of chicken anemia agent. J Gen Virol, v. 7I, p. 819-23, 1990.

37. UO, K.X. et al. Experimental infection of nonenveloped DNA virus (TTV) in Rhesus monkey. J Med Virol, v. 6I, p. I59-64, 2000.

38.VASCONCELOS, H. C. et al. Prevalence and genetic diversity of TT virus genotype 21 (YONBAN virus) in Brazil. J Arch Virol, v. I48, n. 3, p. 517-29, 2003.

39.WU,J. S. Transfusion transmitted virus. Dr.Wu's Liver diseases. (Apr. 2004). Disponível em: http://olddoc.tmu.edu.tw/chiaungo/ profes/TTV.htm. Acesso em: 19 mar. 2004.

40.XIN, X. et al. Mother-to-infant vertical transmission of transfusion transmitted virus in South China. J Perinat Med, v. 32, n. 5, p. 404-6, 2004. 